\title{
Diet and feeding behaviour of juvenile and adult banana prawns Penaeus merguiensis in the Gulf of Carpentaria, Australia
}

\author{
T. J. Wassenberg, B. J. Hill \\ CSIRO Division of Fisheries, Marine Laboratories, PO Box 120, Cleveland, Queensland 4163, Australia
}

\begin{abstract}
The diet of Penaeus merguiensis de Man was studied by examining the contents of the foreguts of 432 juveniles collected from estuarine and 467 adults from offshore habitats in the Gulf of Carpentaria between February 1985 and November 1989. The juveniles in the estuary had fed mainly at night and on rising or near-high tides; the largest amount of food was found in prawns collected $2 \mathrm{~h}$ after high tide. Crustaceans, bivalves, gastropods and polychaetes were the most common food items in the guts of both juveniles and adults. Copepods and other crustaceans were significantly more common in the diet of juvenile prawns caught at night. Foraminiferans, nematodes and algae were found less frequently as the size of the prawns increased. Comparative analysis of foregut contents showed no difference between schooling and non-schooling adult $P$. merguiensis. The study shows that tidal stage, daylight, and the size of $P$. merguiensis affect the composition of the diet.
\end{abstract}

\section{INTRODUCTION}

The banana prawn Penaeus merguiensis de Man is the most abundant penaeid prawn caught commercially in the Gulf of Carpentaria in northern Australia. Juvenile $P$. merguiensis live in coastal wetlands along the mangrove margins of creeks and inlets and mangrove forests along the shore (Chong \& Sasekumar 1981. Staples et al. 1985), probably because the mangroves provide food and shelter (Robertson 1988). During the wet season, the juveniles migrate offshore, where they grow to adulthood (Staples 1980).

The natural diet of adult Penaeus merguiensis from the Straits of Malacca (Hall 1962) and the Philippines (Tiews et al. 1972) has been described but sample sizes were small and were restricted to a narrow size class. Ontogenetic changes in the diet of banana prawns from day-catches in Malaysia (Chong \& Sasekumar 1981) and of only juvenile banana prawns from the east coast of Australia (Robertson 1988) have also been described. Nonetheless, we still do not have a clear picture of how such factors as day-night cycles and tides affect either the diet and feeding patterns of juveniles or the change in diet from juveniles in estuaries to adults offshore.
Juvenile Penaeus merguiensis enter the mangroves during the flooding tide and concentrate along the water's edge as the tide recedes (Staples \& Vance 1979, Robertson 1988). This tidal behaviour may affect their feeding behaviour as it does that of $P$. monodon (Marte 1980) and $P$. duorarum (Sastrakusumah 1971). Staples \& Vance (1979) found that juvenile P. merguiensis of less than $12 \mathrm{~mm}$ carapace length (CL) appeared to feed on the early flooding tide; their foreguts were almost all empty $14 \mathrm{~h}$ later when they emerged from the mangroves as the tide ebbed. However, these authors sampled over a single $24 \mathrm{~h}$ period and did not sample during the night. We therefore extended our study to include diel and tidal effects on the amount of food in the foregut. Such effects are easily identified in animals that clear their guts relatively rapidly. Other species of penaeids do so (Marte 1980 , Hill \& Wassenberg 1987) but it was not known whether $P$. merguiensis does. We therefore measured the rate at which food is cleared from the foregut of juvenile P. merguiensis.

Adult Penaeus merguiensis live offshore where they periodically form aggregations or 'schools' that may contain up to $400 \mathrm{t}$ of prawns (Munro 1973). Why they school is not known; Munro (1973) suggested that they 
may be feeding on preferred food on the seabed. We investigated this possibility by comparing the foregut contents of adult banana prawns collected from schools with those that were not in schools.

\section{MATERIALS AND METHODS}

Laboratory study of foregut clearance rates. The rate of clearance of the foregut of Penaeus merguiensis was measured by Hill's (1976) method. The prawns, held in water at about $24.5^{\circ} \mathrm{C}$ and starved for $24 \mathrm{~h}$, were allowed to feed for $10 \mathrm{~min}$ on peeled and weighed abdomens of Metapenaeus bennettae. The uneaten food was removed, blotted dry and weighed. Batches of 10 prawns were killed by immersion in an ice slurry $0,30,60$ or 90 min after they had fed. The foregut was then removed and the contents dried to constant weight at $70^{\circ} \mathrm{C}$. Ten pieces of abdomen of $M$. bennettae were oven dried at $70^{\circ} \mathrm{C}$ to constant weight to obtain factors for converting wet weight of the food to dry weight.

Diel and tidal effects on feeding of juveniles. Catches of juvenile Penaeus merguiensis are often restricted to short periods of the day or night and the type of tide, because the stage of tide and the daynight cycle all influence catches (Vance \& Staples 1992). The numbers of juveniles caught also tend to drop off sharply after low tide and for a given tide height, catches are greater on the ebb tide than on the flood tide. There is also a seasonal effect. The size range of $P$. merguiensis we wanted (>8.0 $\mathrm{mm} \mathrm{CL}$ ) is only available from November to about April each
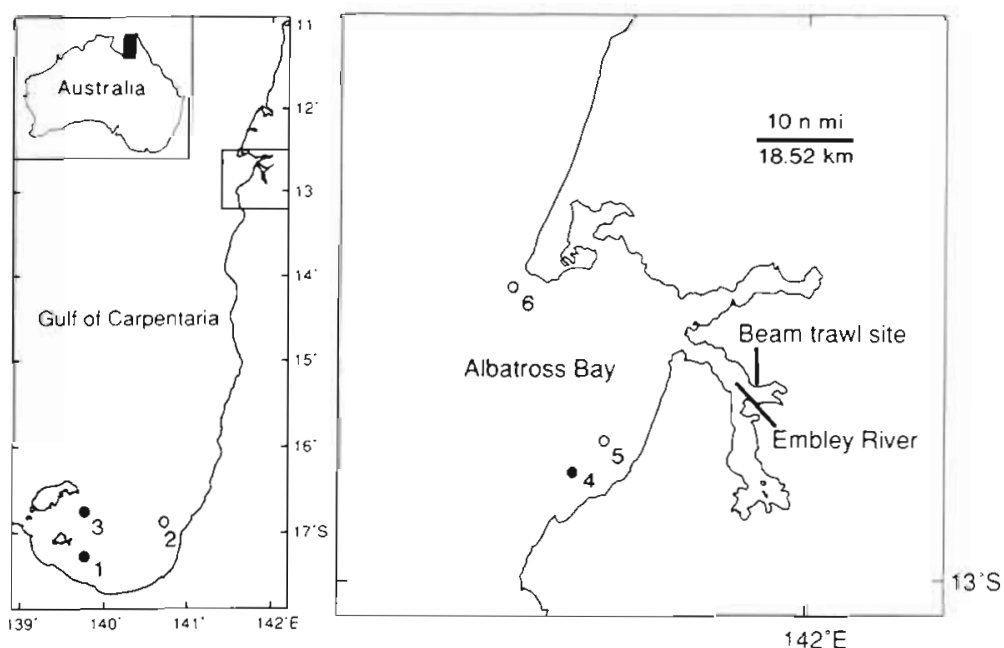

Fig. 1 Study area in the Gulf of Carpentaria, Australia, showing sampling sites for adult prawns [ $(\bullet)$ Sites where schooling prawns were collected; (o) sites where non-schooling prawns were collected and for juvenile prawns in the Embley estuary year. To build up a reasonable sample size and to examine the main effects of day-night and tide stage on the amount of food in the foregut and the type of prey eaten, we collected juveniles over several years and selected stages of the tide

Juvenile Penaeus merguiensis were collected from the Embley estuary at Weipa, Queensland (Fig. 1) with a $1.0 \mathrm{~m} \times 0.5 \mathrm{~m}$ beam trawl, fitted with an $8 \mathrm{~mm}$ stretched mesh net. All the samples were collected from a $200 \mathrm{~m}$ section of the mangrove lined mudbank $14 \mathrm{~km}$ upstream from the mouth of the Embley Estuary (Fig. 1). Trawl hauls were made parallel to the shore on a steeply sloping mudbank in water less than $0.5 \mathrm{~m}$ deep. When the water was in the mangroves, the trawl hauls were made at the edge of the mangroves. Tidal amplitude in this estuary varies from $0.7 \mathrm{~m}$ on the smallest neap tide to $2.4 \mathrm{~m}$ on the largest spring tide. On each occasion, 1 to 3 hauls were made at times corresponding to various stages of the tide during the day and night (Table 1). Each haul lasted about 5 min and the turnaround time between successive hauls was about $3 \mathrm{~min}$. A total of 70 samples was collected. The captured prawns were placed into labelled bags, immediately put on ice and, within $3 \mathrm{~h}$, taken ashore and frozen.

In the laboratory, up to 10 Penaeus merguiensis from each sample were thawed, their carapace lengths (CL) were measured with vernier calipers, and their foreguts were removed. The content of each foregut was weighed (wet weight) and then examined under a microscope. Because no taxonomic studies have been made of the benthic fauna of the region, food items were recorded in broad categories. The number of food items in each foregut was recorded and used to calculate the percentage occurrence.

Foregut weight was log-transformed to remove heterogeneity of variance. An analysis of covariance, with log-size (CL) as covariate, was used to test the hypothesis that foregut content weight did not vary over a tidal cycle or between day and night. The data were comprised of 5 samples each collected over a $24 \mathrm{~h}$ (approximately) period for which 8 tidal stages were defined - 4 during the day and 4 during the night - (Table 1). As not all tidal stages were represented in each sample, there were only 8 degrees of freedom for the sample $x$ tide-stage interaction (Table 2). Tide stage was adjusted for sample differences and the interaction was adjusted for both sample and tide stage. To investigate further the effect of variation in tide, the 7 degrees of freedom 
Table 1 Penaeus merguiensis. Sampling dates, times, tidal levels and number of hauls taken to collect juveniles from a single site in the Embley estuary for analysis of foregut weight and content. Dawn $=06: 30$ to $07: 30 \mathrm{~h}$, day $=07: 30$ to $18: 00 \mathrm{~h}$, dusk $=18: 00$ to $19: 00 \mathrm{~h}$, night $=19: 00$ to $0630 \mathrm{~h}$. $(\mathrm{H}=$ high tide $\pm 2 \mathrm{~h}, \mathrm{~L}=$ low tide $\pm 1 \mathrm{~h}$ )

\begin{tabular}{|c|c|c|c|}
\hline Date & $\begin{array}{l}\text { Time } \\
(\mathrm{h})\end{array}$ & $\begin{array}{l}\text { Tidal } \\
\text { stage }\end{array}$ & $\begin{array}{l}\text { Number } \\
\text { of hauls }\end{array}$ \\
\hline \multirow[t]{2}{*}{03 Mar 87} & $16: 30$ & $\mathrm{H}-2$ & 1 \\
\hline & $21: 01$ & $\mathrm{H}+2$ & 1 \\
\hline \multirow[t]{2}{*}{04 Mar 87} & $06: 00$ & $\mathrm{H}-2$ & 1 \\
\hline & $12: 30$ & $\mathrm{H}+2$ & 1 \\
\hline \multirow[t]{5}{*}{01 Dec 87} & $02: 30$ & $\mathrm{H}+2$ & 3 \\
\hline & $05: 30$ & $\mathrm{~L}-1$ & 3 \\
\hline & $08: 30$ & $L+1$ & 1 \\
\hline & $13: 00$ & $\mathrm{H}-2$ & 1 \\
\hline & $17: 00$ & $\mathrm{H}+2$ & 1 \\
\hline \multirow[t]{4}{*}{02 Dec 87} & $17: 30$ & $\mathrm{H}+1$ & 2 \\
\hline & $19: 00$ & $\mathrm{H}+2$ & 3 \\
\hline & $21: 30$ & $\mathrm{~L}-1$ & 3 \\
\hline & $24: 00$ & $\mathrm{~L}+1$ & 3 \\
\hline \multirow[t]{3}{*}{$03 \mathrm{Dec} 87$} & 03:00 & $\mathrm{H}-2$ & 3 \\
\hline & $05: 00$ & $\mathrm{H}+2$ & 3 \\
\hline & $07: 00$ & $\mathrm{~L}-1$ & 3 \\
\hline 14 Apr 88 & $21: 00$ & $\mathrm{~L}-1$ & 3 \\
\hline \multirow[t]{7}{*}{15 Apr 88} & 01:00 & $L+1$ & 3 \\
\hline & 03:00 & $\mathrm{H}-2$ & 1 \\
\hline & $07: 00$ & $\mathrm{H}+2$ & 1 \\
\hline & 09:00 & $\mathrm{L}-1$ & 1 \\
\hline & $12: 00$ & $L+1$ & 1 \\
\hline & $15: 00$ & $\mathrm{H}-2$ & 1 \\
\hline & $19: 00$ & $\mathrm{H}+2$ & 3 \\
\hline \multirow[t]{2}{*}{7 Nov 89} & $15: 53$ & $\mathrm{H}-2$ & 2 \\
\hline & $19: 14$ & $\mathrm{H}+2$ & 3 \\
\hline \multirow[t]{3}{*}{8 Nov 89} & $05: 36$ & $\mathrm{~L}-1$ & 3 \\
\hline & $07: 43$ & $L+1$ & 3 \\
\hline & $18: 07$ & $\mathrm{H}-2$ & 3 \\
\hline \multirow[t]{4}{*}{9 Nov 89} & $06: 30$ & $\mathrm{~L}-1$ & 2 \\
\hline & $08: 30$ & $\mathrm{~L}+1$ & 3 \\
\hline & $13: 44$ & $\mathrm{H}-2$ & 2 \\
\hline & $17: 48$ & $\mathrm{H}+2$ & 2 \\
\hline
\end{tabular}

for tide stage were subdivided into single degrees of freedom for comparisons of: night $x$ day; falling tide $x$ rising tide; high tide $x$ low tide and their interactions (Table 2). The sample $\times$ tide stage interaction was used as the error term because the variation due to this term was greater than the variation between prawns caught in the same sample at the same tide stage.

Not all prey occurred in every foregut examined. Because of the large number of zeros recorded for each prey category, we used non-parametric tests in our analysis of the number of prey eaten during the day or night or during different tide stages. In this instance a Mann-Whitney $U$-test was used to test the hypothesis that there were no diel differences with day/night as the independent variable. A Kruskal-Wallis test was
Table 2. Penaeus merguiensis. Details of the analysis of covariance for the log of gut content weight of juveniles collected from a $200 \mathrm{~m}$ section of a mangrove lined bank in the Embley estuary. $p<0.05 ; \cdots p<0.001 ; \Phi=0.05<p<0.10$

\begin{tabular}{|lrl|}
\hline Source of variation & df & Mean square \\
\hline (a) Covariate & & \\
$\quad$ Size & 1 & $5.73 \cdots$ \\
$\quad$ Factors & & \\
$\quad$ Samples & 4 & $0.69 \Phi$ \\
$\quad$ Tide stage & 7 & $0.54 \Phi$ \\
$\quad$ Sample $\times$ tide stage & 8 & $0.203^{\cdots}$ \\
$\quad$ Residual & 411 & 0.057 \\
(b) Analysis of tide phase components & & \\
$\quad$ Night vs day & 1 & $1.422^{\circ}$ \\
$\quad$ Falling vs rising tide & 1 & 0.02 \\
$\quad$ Night-day $\times$ fall-rise & 1 & 0.17 \\
$\quad$ Low vs high tide & 1 & $1.16^{\circ}$ \\
$\quad$ Night-day $\times$ low-high tide & 1 & 0.04 \\
$\quad$ Fall-rise $\times$ low-high tide & 1 & 0.53 \\
$\quad$ Night-day $\times$ fall-rise & 1 & 0.46 \\
$\quad \times$ low-high tide & 8 & 0.203 \\
$\quad$ Residual (Sample $\times$ tide stage) & & \\
& & \\
& &
\end{tabular}

used to test the hypothesis that there were no nocturnal tidal differences in the diet of Penaeus merguiensis. The test was repeated for each prey category with the tidal stages as the independent variable.

Ontogenetic changes in diet. To examine ontogenetic changes in diet, we collected juvenile Penaeus merguiensis from the Embley estuary and adults from offshore in Albatross Bay. As errors in estimates of dietary importance due to different digestion rates of tissues may be minimised by sampling during or close to the peak period of feeding (Hyslop 1980), we made a preliminary analysis of diel and tidal effects on feeding. The foreguts of the juveniles were fullest at night and those of the adult prawns did not show a diel effect, so only samples collected at night were used. All the samples for this comparison were collected over 2 nights during December 1987 to minimise possible changes in prey availability over time or any other temporal effects. On the first night, the juveniles were collected from a single haul along the edge of the mangrove-lined mudbank of the estuary and the following night the adults were collected from a single haul in about $15 \mathrm{~m}$ deep waters offshore.

After capture, the juveniles $(n=113)$ were stored in an ice slurry and then frozen while the adults $(n=100)$ were immediately frozen on board the trawler. In the laboratory, the carapace length of each prawn was measured and the contents of the foregut were removed and examined. The number of items in each food category was recorded. A Kruskal-Wallis analysis of variance was used to test the null hypothesis that 
there was no difference in the number of each prey eaten by the different size-classes of Penaeus merguiensis. This test was repeated for each prey item across the size classes.

Diet of schooling and non-schooling adult prawns. Adult schooling and non-schooling Penaeus merguiensis were collected from chartered commercial and research prawn trawlers from 6 sites in the Gulf of Carpentaria (Fig. 1) during the 5 mo period when commercial fishing was not permitted. The prawns were frozen immediately and the foregut contents analysed as described above. The number of items in each food category was recorded and the frequency of occurrence and the numerical composition for each food category were calculated.

It was suggested that the schooling behaviour of Penaeus merguiensis may be a response to the presence or absence of a particular food item (Munro 1973). In order to examine for differences in diet between sexes in each of the samples and between schooling and non-schooling prawns (samples combined) we used the Mann-Whitney $U$-test on individual prey types and repeated the test for each prey category.

\section{RESULTS}

\section{Foregut clearance rate}

In the laboratory, juvenile Penaeus merguiensis (17.3 to $24.6 \mathrm{~mm} \mathrm{CL}$ ) ate up to $20 \mathrm{mg}$ of tissue (wet weight) in 10 min of feeding. Nearly $20 \%$ of that amount was lost by the prawn shredding its food; only about $80 \%$ was found in the foregut of prawns killed immediately after feeding (time 0 min). Soft tissue was quickly

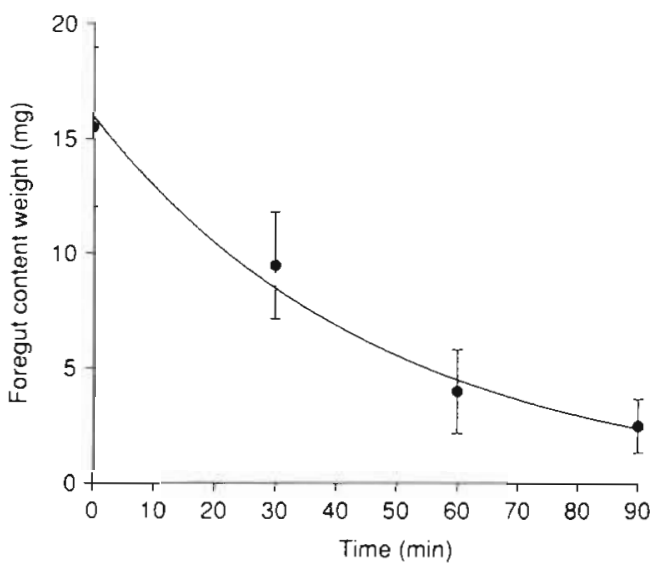

Fig. 2. Penaeus merguiensis. Mean dry weight ( $\pm 2 \mathrm{SE}$ ), of soft tissue in the foregut of juveniles at intervals after feeding was stopped. $\mathrm{n}=10$ at each point. The curved line is an exponential function: $y=15.2 \mathrm{e}^{-0.02145 x}$ digested: only $60 \%$ of ingested material remained in the foregut after $30 \mathrm{~min}$ and less than $18 \%$ after $90 \mathrm{~min}$ (Fig. 2). The rate of clearance may be described by the exponential decay function:

Foregut content weight $(\mathrm{mg})=15.2 \mathrm{e}^{-00214 j \text { Timelmin }}$.

\section{Diel and tidal effects on feeding in juveniles}

The foregut contents of 432 juvenile Penaeus merguiensis (8.0 to $21.1 \mathrm{~mm} \mathrm{CL}$ ) collected over 5 (each approximately $24 \mathrm{~h}$ ) sampling periods in the Embley estuary were weighed. Of the prawns caught in the estuary during daytime $(06: 30 \mathrm{~h}$ to $18: 30 \mathrm{~h}), 10 \% \mathrm{had}$ empty foreguts. Only $1.6 \%$ of those caught at night $(18: 30 \mathrm{~h}$ to $06: 30 \mathrm{~h})$ had empty foreguts.

In the analysis of covariance, the coefficient for the covariate (log-size) was $1.53(\mathrm{SE}=0.17, t=9.02)$. The interaction of sample $\times$ tide stage was highly significant $(\mathrm{p}<0.001)$ and the systematic sample and tide stage effects were nearly significant $(0.05<p<0.10)$ when compared with the interaction (Table 2). In further analysis of the components of tide stage, only night vs day and low vs high tide were significant $(\mathrm{p}<$ 0.05) (Table 2).

Juvenile Penaeus merguiensis had significantly ( $\mathrm{p}<$ 0.05 ) more food in their foregut at night (adjusted mean log weight $=0.288 \mathrm{~g}, \mathrm{SE}=0.029$ ) than during the day (adjusted mean $\log$ weight $=0.169 \mathrm{~g}$, $\mathrm{SE}=0.045$; Fig. 3). The quantity of food in the foregut showed that most feeding took place just after dusk, between 18 and 20 h (Fig. 4).

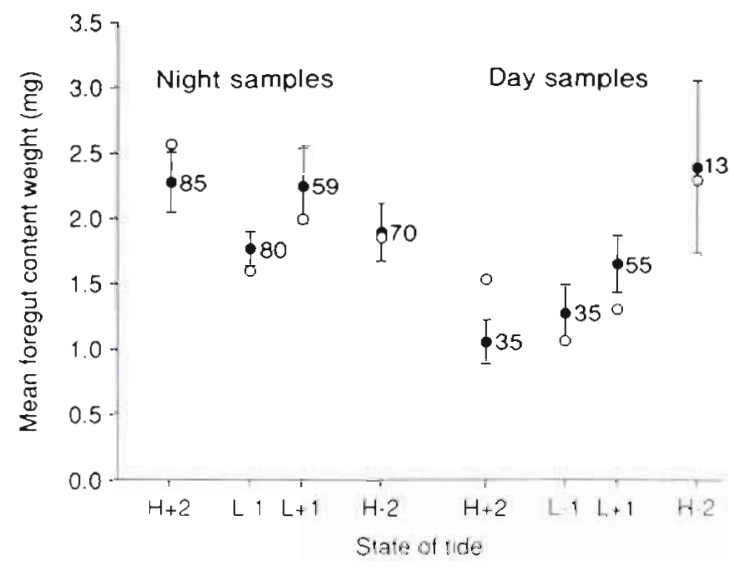

Fig. 3. Penaeus merguiensis. Mean foregut content weights $( \pm 2 \mathrm{SE}$ ) of juvenile prawns collected at each tidal stage dunng the day and night over 10 diel periods. (0) Same data adjusted for the size of the prawns. Sample size is shown next to each point. $(\mathrm{H} \pm 2$ indicates high tide $\pm 2 \mathrm{~h} ; \mathrm{L} \pm 1$ indicates low tide $\pm 1 \mathrm{~h}$ ). The tidal stages are spaced on a time scale of $6 \mathrm{~h}$ between low and high tide 


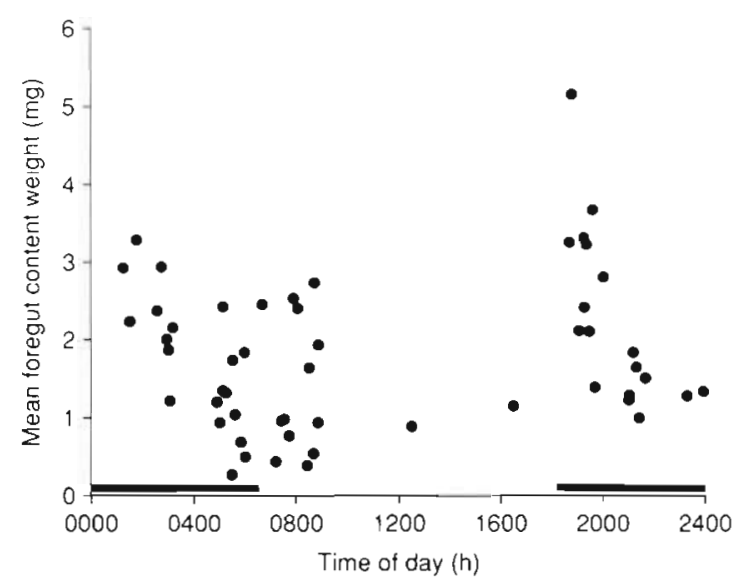

Fig. 4. Penaeus merguiensis. Mean weight of foregut content at various times of collection over 10 diel periods in the Embley estuary, $\mathrm{n}=6$ to 10 at each point. Dark bar indicates night

The weight of food in the foregut at night was greater in juvenile Penaeus merguiensis caught on the flooding tide $(\mathrm{L}+1)$ and $2 \mathrm{~h}$ after high tide $(\mathrm{H}+2)$ than in those caught $1 \mathrm{~h}$ before low tide ( $\mathrm{L}-1$ ) (Fig. 3 ). The difference was significant $(p<0.05)$. The average weight of all the foregut contents, for all samples combined, was greatest $2 \mathrm{~h}$ after high tide $(\mathrm{H}+2)$ at night and was lowest at $1 \mathrm{~h}$ before low tide $(\mathrm{L}-1)$ during the day (Fig. 3).
As the mean size of Penaeus merguiensis collected was not significantly different between night and day it was possible to test for differences in the frequency of prey in the diet between night and day. Vascular plant material, harpacticoid copepods and crustaceans were significantly more frequent in the diet during the night than during the day (Table 3). Similarly, the mean size of $P$. merguiensis caught at different nocturnal tidal stages was not significantly different, allowing us to test for differences in diet at 4 tide stages. Compared to the other samples, 8 prey items were significantly different with 7 being more frequent in the diet of samples collected 1 h after low tide $(L+1)$ (Table 2), while crustaceans were more frequent in the diet $2 \mathrm{~h}$ before high tide $(\mathrm{H}-2)$.

\section{Ontogenetic changes in diet}

Ontogenetic differences were found for many prey items in the diet of Penaeus merguiensis from the Embley estuary and Albatross Bay. With increasing prawn size, foraminiferans, algae and nematodes decreased in frequency (Fig. 5) and were rarely found in adult prawns offshore. In contrast, bivalves, gastropods and polychaetes rose significantly ( $p<0.05$ ) (Fig. 6). The occurrence of crustaceans was high in the diet of both juvenile and adult prawns. Small amounts of fishbones

Table 3. Penaeus merguiensis. Diel and nocturnal tidal differences in the frequency of occurrence of prey in the diet of juveniles in the Embley Estuary. $p<0.05, \cdots p<0.001 . H=$ high tide $\pm 2 \mathrm{~h}, \mathrm{~L}=$ low tide $\pm 1 \mathrm{~h}$

\begin{tabular}{|c|c|c|c|c|c|c|}
\hline \multirow[t]{2}{*}{ Prey items } & \multicolumn{2}{|c|}{$\%$ Frequency of occurrence for: } & \multicolumn{4}{|c|}{ Tidal stage (night) } \\
\hline & Day & Night & $\mathrm{H}+2$ & $\mathrm{~L}-1$ & $L+1$ & $\mathrm{H}-2$ \\
\hline Teleostei & 3.6 & 3.1 & 3.5 & 0.0 & 6.8 & 2.9 \\
\hline \multicolumn{7}{|l|}{ Mollusca } \\
\hline Bivalvia & 3.6 & 5.1 & 9.4 & 2.5 & 10.2 & $0.0^{*}$ \\
\hline Gastropoda & 34.8 & 32.0 & 25.9 & 27.5 & 54.2 & $25.7^{\cdots} \cdots$ \\
\hline Scaphopoda & 2.2 & 2.0 & 1.2 & 1.3 & 6.8 & $0.0 \cdots$ \\
\hline \multicolumn{7}{|l|}{ Crustacea } \\
\hline Decapoda & 8.0 & 6.5 & 9.4 & 1.2 & 13.6 & $2.9 \cdots$ \\
\hline Copepoda & 15.6 & $21.4 \cdots$ & 28.2 & 12.5 & 22.0 & 22.9 \\
\hline Other & 40.6 & $57.8 \cdots$ & 65.0 & 46.2 & 35.6 & $80.0^{\cdots}$ \\
\hline \multicolumn{7}{|l|}{ Annelida } \\
\hline Polychaeta & 12.3 & 8.1 & 7.1 & 3.7 & 11.9 & 11.4 \\
\hline \multicolumn{7}{|l|}{ Protozoa } \\
\hline Foraminifera & 33.3 & 26.5 & 27.1 & 17.5 & 42.4 & $22.9 \cdots$ \\
\hline Plant material (vascular) & 4.3 & $11.2^{\circ}$ & 14.1 & 1.2 & 25.4 & $7.1 \cdots$ \\
\hline Algae & 18.1 & 12.6 & 14.1 & 10.0 & 11.9 & 14.3 \\
\hline Unidentified & 29.7 & 24.8 & 17.6 & 30.0 & 40.7 & $14.3 \cdots$ \\
\hline Sand & 0.7 & 2.7 & 2.4 & 1.2 & 1.7 & 5.7 \\
\hline Mean prawn size & 13.09 & 12.9 & 12.98 & 12.7 & 13.6 & 12.7 \\
\hline $2 \mathrm{SE}$ & 0.40 & 0.29 & 0.64 & 0.52 & 0.58 & 0.5 \\
\hline (n) & $(138)$ & $(294)$ & $(85)$ & $(80)$ & (59) & $(70)$ \\
\hline
\end{tabular}




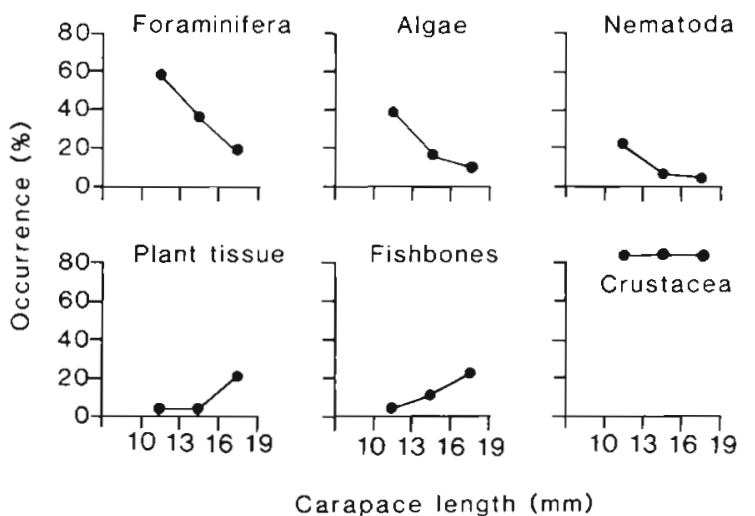

Fig. 5. Penaeus merguiensis. Frequency of occurrence of 6 food items in the foregut of $3 \mathrm{~mm}$ size classes of juvenile prawns collected at night in the Embley estuary. Sample sizes for successive sizes are 29,35 and 49

(Fig. 5) were found in the foreguts of juvenile prawns from the estuary, while fish scales (>2.0 mm diam.), but no fish bones, were found in the foreguts of adult prawns offshore (Fig. 6).

\section{Diet of schooling and non-schooling prawns}

The foregut contents of 232 schooling and 235 nonschooling Penaeus merguiensis were compared. No difference between sexes was found in the diet between schooling and non-schooling prawns, except in one sample where polychaetes were significantly
( $p<0.05$ ) more numerous in the diet of the male prawns. Schooling prawns (samples combined) had more prey items (1868) in their foreguts than nonschooling prawns (1598). About $2 \%$ of schooling prawns and $7 \%$ of non-schooling prawns had empty foreguts. The same range of dietary items was found in the diet between schooled and non-schooled $P$. merguiensis collected from all 6 sites (Table 4).

There were quantitative differences in the numbers of prey eaten by schooling and non-schooling Penaeus merguiensis (samples combined). In a plot of percentage numerical composition vs percentage frequency of occurrence (Fig. 7), fish scales (Teleostei) were statistically the most numerous food item in schooled prawns $(\mathrm{p}<0.05)$ but were eaten by relatively few prawns ( 20 to $25 \%$ ) as can be noted by the tall narrow shape of the histogram for fish scales. Bivalves were significantly $(\mathrm{p}<0.05)$ more numerous and were eaten by about $80 \%$ of schooling prawns, while crustaceans, gastropods, echinoderms and unidentified tissue were more numerous and were eaten by about 60 to $80 \%$ of non-schooling prawns (Fig. 7). However, these quantitative differences between schooling and non-schooling prawns do not support the hypothesis that schooling behaviour may be a response to the presence or absence of a particular food type.

\section{DISCUSSION}

Despite being fragmented, most of the prey of Penaeus merguiensis could be identified to broad taxo-

\section{Fish scales}

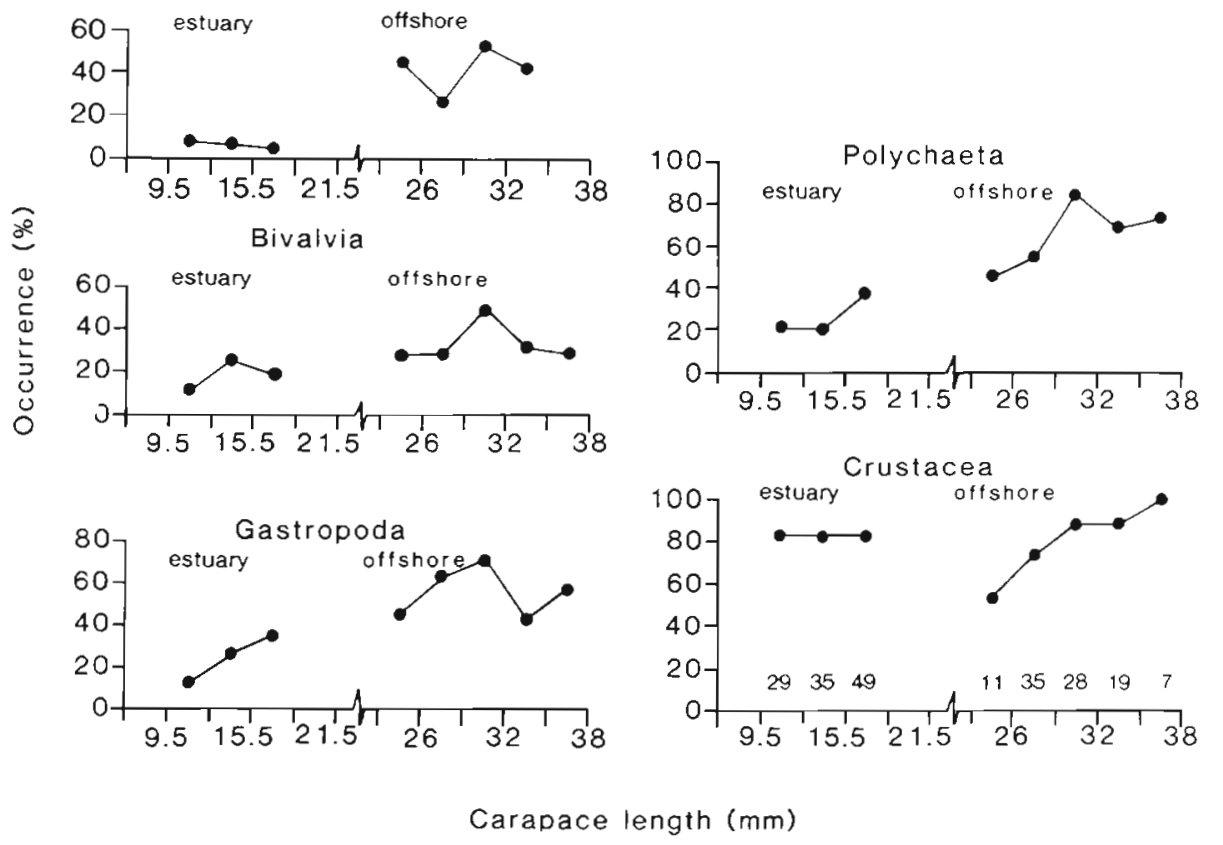

Fig. 6. Penaeus merguiensis Frequency of occurrence of 5 food items in the foregut of $6 \mathrm{~mm}$ size classes of juvenile prawns collected at night from the Embley estuary and from $3 \mathrm{~mm}$ size classes of adult prawns collected from Site 6 in Albatross Bay (offshore). Sample sizes for each point are indicated in the Crustacea figure 
Table 4. Penaeus merguiensis. Diet of prawns and statistical data for these samples collected from 6 locations in the Gulf of Carpentaria. Diets are expressed as percentage numerical composition

\begin{tabular}{|c|c|c|c|c|c|c|}
\hline \multirow[t]{2}{*}{ Diet } & \multicolumn{3}{|c|}{ Schooling } & \multicolumn{3}{|c|}{ Non-schooling } \\
\hline & Site 1 & Site 3 & Site 4 & Site 2 & Site 5 & Site 6 \\
\hline \multicolumn{7}{|l|}{ Pisces } \\
\hline Teleostei & 61.0 & 3.6 & 43.4 & 24.4 & 22.4 & 16.6 \\
\hline \multicolumn{7}{|l|}{ Mollusca } \\
\hline Bivalvia & 8.5 & 33.3 & 36.4 & 15.6 & 12.2 & 7.8 \\
\hline Gastropoda & 3.9 & 15.8 & 3.5 & 17.4 & 25.2 & 20.3 \\
\hline Scaphopoda & 0.0 & 0.0 & 3.3 & 0.0 & 3.7 & 2.0 \\
\hline Crustacea & 8.6 & 16.6 & 5.6 & 8.4 & 17.8 & 33.7 \\
\hline \multicolumn{7}{|l|}{ Annelida } \\
\hline Polychaeta & 2.9 & 16.8 & 5.6 & 6.1 & 8.4 & 15.5 \\
\hline \multicolumn{7}{|l|}{ Echinodermata } \\
\hline Echinoidea & 2.3 & 3.1 & 0.0 & 1.3 & 0.9 & 0.0 \\
\hline Ophiuroidea & 3.0 & 1.0 & 0.7 & 2.2 & 1.9 & 0.6 \\
\hline \multicolumn{7}{|l|}{ Protozoa } \\
\hline Foraminifera & 5.7 & 8.0 & 1.1 & 3.7 & 0.0 & 0.8 \\
\hline Other & 0.8 & 0.8 & 0.2 & 19.4 & 0.0 & 2.7 \\
\hline Unidentified & 3.3 & 1.0 & 0.2 & 1.5 & 7.5 & 0.0 \\
\hline Total no. of prey items & 1056 & 386 & 426 & 1002 & 107 & 489 \\
\hline Sample size & 100 & 98 & 34 & 100 & 35 & 100 \\
\hline Mean size CL $(\mathrm{mm})$ & 30.1 & 28.0 & 32.2 & 30.2 & 34.2 & 29.9 \\
\hline Percentage with empty foregut & 3.0 & 2.0 & 1.0 & 5.0 & 8.5 & 7.0 \\
\hline Sampling date & Mar 85 & Feb 85 & Apr 88 & Feb 85 & Apr 88 & Dec 86 \\
\hline
\end{tabular}

nomic groups. Much of the soft tissue was attached to or could be associated with hard parts of teleosts, molluscs, polychaetes or crustaceans. This helped reduce the bias from differential rates of tissue digestion. Furthermore, the samples were collected when the prawns were actively feeding which further reduced the bias (Hyslop 1980).

Penaeus merguiensis clears soft tissues in about $100 \mathrm{~min}$. This is slightly slower than $P$. esculentus, which empties its foregut in about 60 min at the same temperatures (Hill \& Wassenberg 1987) but faster than P. monodon, which clears about $50 \%$ within $1 \mathrm{~h}$ of feeding (Marte 1980). The rate at which penaeids clear hard parts does not appear to have been studied, but their absence from the foregut of $P$. esculentus caught shortly after their emergence from the substrate in the evening indicates that they can be cleared within $12 \mathrm{~h}$ (Wassenberg \& Hill 1987). Juvenile $P$. merguiensis collected at night, 2 h after high tide, had a large amount of food in their foregut. Juveniles collected 3 h later, 1 h before low tide, had very little soft food or hard parts in their foregut, which suggests that they may be able to clear hard parts within a few hours.
The feeding behaviour of juvenile Penaeus merguiensis is affected by the state of the tide and by light. Our results show that juvenile $P$. merguiensis

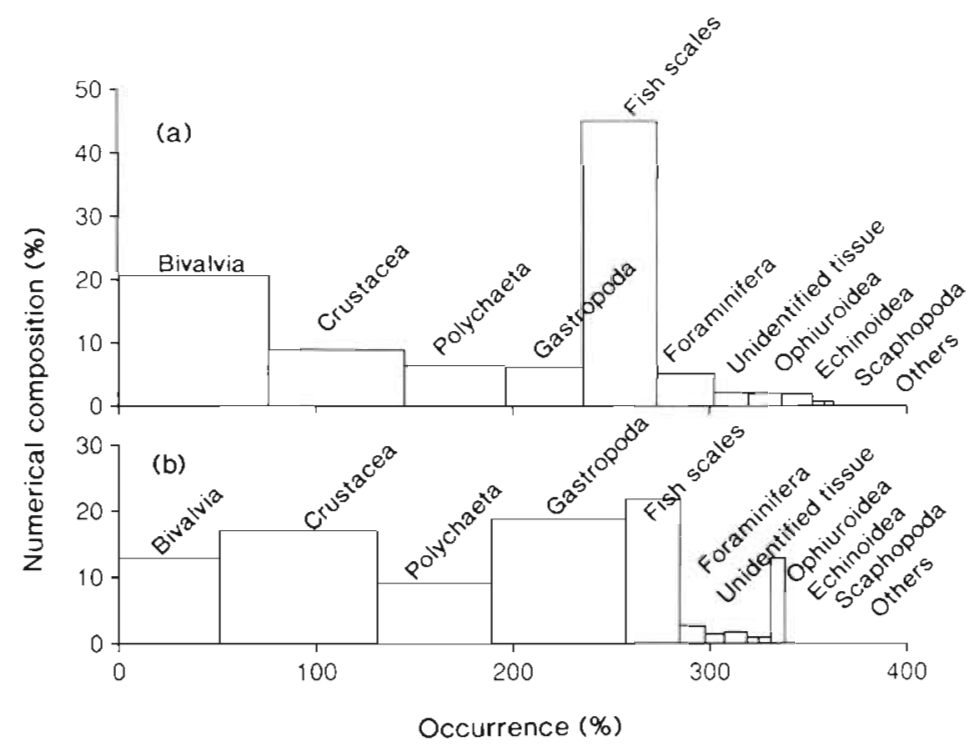

Fig. 7 Penaeus merguiensis. Relative importance of food items in (a) schooling ( $\mathrm{n}=98$, collected from Site 3, SE Gulf of Carpentaria) and (b) non-schooling prawns ( $\mathrm{n}=100$, collected from Site 2, SE Gulf of Carpentaria) 
feed as the tide rises. Prawns caught at night when the tide recedes have full foreguts but their foreguts are only half full if they are caught on an ebbing tide during the day. An hour before low tide their foreguts were nearly empty, which suggests that feeding stopped around mid-ebb tide. The juvenile prawns do not appear to feed as often during the day as at night. Staples \& Vance (1979) found that juvenile P. merguiensis feed on a flooding tide during the day as does $P$. duorarum (Sastrakusumah 1971), but their sample was from a single $24 \mathrm{~h}$ period and they could not catch the prawns for much of that time. We had difficulty collecting juvenile $P$. merguiensis during the day after about 08:30 h (Fig. 4). Vance \& Staples (1992) found that the catchability of $P$. merguiensis decreases with increasing light; the prawns are most catchable at low tide at night.

The most abundant food items found in juvenile and adult Penaeus merguiensis were crustaceans, molluscs and polychaetes. These groups are also the main food for many species of Penaeus, including $P$. duorarum, $P$. setiferus and $P$. aztecus (Williams 1955), P. monodon (Chaitiamvong 1980, Marte 1980), P. semisulcatus (Thomas 1980, Wassenberg \& Hill 1987), $P$. esculentus (Moriarty \& Barclay 1981, Wassenberg \& Hill 1987) and P. latisulcatus (Moriarty \& Barclay 1981). These food items were also reported in the foreguts of 31 species of penaeids, of 6 genera (Metapenaeus, Metapenaeopsis, Penaeus, Parapenaeus, Solenocera, Trachypenaeus), from the IndoWest Pacific (Hall 1962).

The diet of juvenile Penaeus merguiensis reported in this study is similar to that reported in other studies of this species, but there are also important differences. Our finding that $P$. merguiensis ate mainly crustaceans, molluscs and polychaetes was similar to the findings of Chaitiamvong (1980), Chong \& Sasekumar (1981), Moriarty \& Barclay (1981) and Robertson (1988). Foraminifera were numerous in the diet of the juvenile prawns collected during our study and from the studies by Chong \& Sasekumar (1981) and Moriarty \& Barclay (1981), while Robertson (1988) found that Foraminifera were only a minor dietary item of juvenile $P$. merguiensis. Insect remains were reported by Chong \& Sasekumar (1981) and Robertson (1988), and detrital material by Robertson (1988), but we did not find these in the diet of juvenile $P$. merguiensis from the Embley Estuary.

Detritus has been defined by Velimirov et al. (1981) as dead material of unrecognisable origin. With care, most material in penaeid guts can be assigned to its origin, and semi-digested molluscs, crustaceans and polychaetes should not be called detritus merely because they are not intact (Dall et al. 1990).
Harpacticoid copepods and other crustaceans were significantly more numerous in the diet of prawns caught at night than during the day, probably because the availability of prey for juvenile $P e$ naeus merguiensis varied with light and tidal level. Our study suggests that the juveniles are less active, or at least feed less during the daytime than at night. They certainly were less catchable during the day. Hindley (1975) found that, in the laboratory, juvenile $P$. merguiensis were more, but not exclusively, active at night. In a laboratory study that simulated tidal effects but excluded a day-night cycle, Vance (1992) found that the prawns were most active around or just after high tide and were least active near low tide. When he imposed a day-night cycle as well as a tidal cycle, the prawns were most active near high tide, at night. Reduced activity during the day may explain some of the diel differences we found in the diets of $P$. merguiensis. Alternatively, the prey may become more active and more vulnerable to predation by prawns on the flooding tide at night. In nearshore waters polychaetes, mysids, various amphipods and other crustaceans emerge from the substratum into the water column at night (Hobson \& Chess 1976,1979$)$. The prey eaten by $P$. merguiensis during our study - harpacticoid copepods, amphipods, cumaceans, tanaids, ostracods and polychaetes - are found near the bottom during the day and move up in the water column at night (Jacoby \& Greenwood 1988).

Some of the ontogenetic differences in the diet of Penaeus merguiensis, such as the decrease in occurrence of small prey items like foraminiferans, nematodes, copepods and algae in the larger prawns, may reflect changes in the prawns' ability to manipulate small prey. Other differences could be due to availability of food items; for example, algae were virtually absent from the diet of adult prawns collected offshore. Changes in diet with increasing body size have been found in other studies of penaeids P. merguiensis (Hall 1962, Robertson 1988) and $P$. esculentus and $P$. semisulcatus (Wassenberg \& Hill 1987).

It has been suggested that the schooling behaviour of Penaeus merguiensis may be a response to the presence or absence of a particular food item (Munro 1973). The results of our study do not support this hypothesis. Except for prawns from schools associated with fish, there were no noteworthy differences in diet between schooling and non-schooling prawns.

Acknowledgements. The sampling for the juvenile prawns was assisted by D. Vance, M. Haywood, R. Cross, and D. Heales. J. Kerr assisted with the statistical analysis. D. Vance and Dr P. Rothlisberg made useful comments on early drafts of the manuscript. 


\section{LITERATURE CITED}

Chaitiamvong, S. (1980). The biology of penaeid shrimp in Thailand. In: Report of the workshop on the biology and resources of the penaeid shrimps in the South China Sea area - Part 1, 30 June-5 July, Kota Kinabulu, Sabah, Malaysia. FAO/UNDP, Manila, p. 64-69

Chong, V. C., Sasekumar, A. (1981). Food and feeding habits of the white prawn Penaeus merguiensis. Mar. Ecol. Prog. Ser, 5: 185-191

Dall, W., Hill, B. J., Rothlisberg, P. C., Staples, D. J. (1990). The biology of the Penaeidae. Adv. mar. Biol. 27: 1-489

Hall, D. N. F. (1962). Observations on the taxonomy and biology of some Indo-West Pacific Penaeidae (Crustacea, Decapoda). Colonial Office Fishery Publication 17, HMSC, London

Hill, B. J. (1976). Natural food, foregut clearance-rate and activity of the crab Scylla serrata. Mar. Biol. 34: 109-116

Hill, B. J., Wassenberg, T J. (1987). Feeding behaviour of adult tiger prawns, Penaeus esculentus, under laboratory conditions. Aust. J. mar. Freshwat. Res. 38: 183-190

Hindley, J. P. R. (1975). Effects of endogenous and some exogenous factors on the activity of the juvenile banana prawn Penaeus merguiensis. Mar. Biol. 29: 1-8

Hobson, E. S., Chess, J. R. (1976). Trophic interactions among fishes and zooplankters near shore at Santa Catalina lsland, California. Fish. Bull. U.S. 74: 567-598

Hobson, E. S., Chess, J R. (1979). Zooplankters that emerge from the lagoon floor at night at Kure and Midway Atolls, Hawaii. Fish. Bull. U.S. 77: 275-280

Hyslop, E. J. (1980). Stomach content analysis - a review of methods and their application. J. Fish Biol. 17: 411-429

Jacoby, C. A., Greenwood, J. G. (1988). Spatial, temporal and behavioural patterns in emergence of zooplankton in the lagoon of Heron Reef, Great Barrier Reef, Australia. Mar. Biol. 97: 309-328

Marte, C. L. (1980). The food and feeding habit of Penaeus monodon Fabricius collected from Makato River, Aklan, Philippines (Decapoda Natantia). Crustaceana 38: $225-236$

Moriarty, D. J. W., Barclay, M. C. (1981). Carbon and nitrogen content of food and the assimilation efficiencies of penaeid prawns in the Gulf of Carpentaria. Aust. J. mar. Freshwat. Res. 32: 245-251

Munro, I. S. R. (1973). Biology of the banana prawn (Penaeus merguiensis) in the south-east corner of the Gulf of Carpentaria. In: Young, P. C. (ed.) First Australian National

This article was submitted to the editor
Prawn Seminar. Australian Government Publishing Service, Canberra, p. 60-78

Robertson, A. I. (1988). Abundance, diet, and predators of juvenile banana prawns. Penaeus merquiensis, in a tropical mangrove estuary. Aust. J. mar. Freshwat. Res. 39: $467-478$

Sastrakusumah, S. (1971). A study of the food of juvenile migrating pink shrımp. Penaeus duorarum Burkenroad. University of Miami, Sea Grant Tech. Bull. 9: 1-37

Staples, D. J. (1980). Ecology of juvenile and adolescent banana prawns, Penaeus merguiensis, in a mangrove estuary and adjacent off-shore area of the Gulf of Carpentaria. II. Emigration, population structure and growth of juveniles. Aust. J. mar. Freshwat. Res. 31: 653-665

Staples, D. J., Vance, D. J. (1979). Effects of changes in catchability on sampling of juvenile and adolescent banana prawns, Penaeus merguiensis de Man. Aust. J. mar. Freshwat. Res. 30: 511-519

Staples, D. J., Vance, D. J., Heales, D. J. (1985). Habitat requirements of juvenile penaeid prawns and their relationship to offshore fisheries. In: Rothlisberg, P. C., Hill, B. J., Staples, D. J. (eds.) Second Australian National Prawn Seminar. NPS2, Cleveland, p. 47-54

Thomas, M. M. (1980). Food and feeding habits of Penaeus semisulcatus de Haan at Mandapam. Indian J. Fish. 27 : $130-139$

Tiews, K., Bravo, S. A., Ronquillo, I. A. (1972). On the food and feeding habits of some Philippine shrimps in Manila Bay and San Miguel Bay. Proc. Indo-Pacific Fish. Coun. 13: $85-92$

Vance, D. J. (1992). Activity patterns of juvenile penaeid prawns in response to artificial tidal and day-night cycles: a comparison of three species. Mar. Ecol. Prog. Ser. 87: $215-226$

Vance, D. J., Staples, D. J. (1992). Catchability and sampling of three species of juvenile penaeid prawns in the Embley River, Gulf of Carpentaria, Australia. Mar. Ecol. Prog. Ser. 87: $201-213$

Velimirov, B., Ott. J. A., Novak, R. (1981). Microorganisms on macrophyte debris: biodegradation and its implication in the food web. Kieler Meeresforsch., Sonderh. 5: 333-334

Wassenberg, T J., Hill, B. J (1987). Natural diet of the tiger prawns Penaeus esculentus and $P$. semisulcatus. Aust. J. mar. Freshwat. Res. 38: 169-182

Williams, A. B. (1955). A contribution to the life histories of commercial shrimps (Penaeidae) in North Carolina. Bull mar. Sci. Gulf Caribb. 5: 116-146

Manuscript first received: October 13, 1992

Revised version accepted: February 2, 1993 